\title{
Civic Education as Empowerment of Civic Activism
}

\author{
Erwin Susanto* and Nadya Putri Saylendra \\ Civic Education Program \\ Universitas Buana Perjuangan Karawang \\ Karawang, Indonesia \\ *susanto@ubpkarawang.ac.id
}

\begin{abstract}
This article was created to explain about the role of civic education to empower civic activism. Learning civics education in the field are still oriented on mastering the theory and memorize, the school curriculum tends to be stiff and full load will become unattractive and unable to cultivate creativity in students so the success of the learning process being hampered. During this time, the civic education learning focus solely to the understanding and mastery of the material from the learning of civic education course. In practice, students are only allowed as objects to measure how much students can master the materials given by the teacher. This certainly will only sharpen the student's cognitive and ignores the psychomotor aspects and ignores the attitude. This kind of education does not prepare students to be able to interact with both their environment when they later assimilated into society. After conducting a study of the literature, the authors can say that civic education is perfect to strengthen civic activism. It is in accordance with the goals of citizenship education in General which is "to form good citizens (to be a good citizen)". Through this article the author recommends changing the paradigm of civic education educator long conventional civic education toward understanding put forward not only theory but also a learning experience. So being able to empower civic activism to the maximum.
\end{abstract}

Keywords - civic education; civic activism; civic engagement

\section{INTRODUCTION}

Currently, citizenship education is trying to develop new patterns for Civic Education in the 21st century a new pattern of civic education is explained that civic education vision for the future is as education about, through, and for citizenship [1]. Continuing this vision, in future Citizenship Education has the mission of socio-pedagogical, socio-academic and socio-cultural that allows the development and cultivation of civic knowledge, civic virtue and civic culture in an integrated and sustainable [2]. All of the above civics mission is basically aimed to develop civic intelligence and civic participation of every citizen of Indonesia to the front [3]. From some of these opinions can be understood that the citizenship education will be a catalyst to accelerate and empower civics activism.

Civic education is one of the areas of study that expands the national mission for educating the nation of Indonesia through the corridor "value-based education". Civics configuration or systemic framework built on the paradigm as follows: first, civic education in curricular are designed as a subject of study that aims to develop the potential of individuals to become Indonesian citizens were noble, smart, participatory, and accountable. Second, civic education theoretically designed as a subject of study which includes the dimensions of cognitive, affective, and psychomotor which is confluent or interpenetrating and integrated in the context of the substance of ideas, values, concepts, and moral Pancasila, democratic citizenship, and civil defense. Third, civic education are pragmatically designed as a subject of study that emphasizes the content that carries values (content embedding values) and experiential learning (learning experiences) in the form of a variety of behaviors that need to be realized in everyday life and the life guidance for citizens in society, nation and state as a further elaboration of ideas, values, concepts and moral Pancasila, democratic citizenship, and civil defense [4]

One form of efforts to empower civics activism, civic education also carrying the mission of learning democracy, in democracy, and for democracy [2]. Branson also said that citizenship education should be a major concern. No task is more important than the development of citizens who have the knowledge, skills and character needed to correct a commitment to the values of fundamental principles and democracy [5]. In line with the statement, the purpose of civic education lessons in general that for the sake of educating citizens in order to become a good citizen. Which can be painted with "patriotic citizens, tolerant, faithful to the nation and state, religious, democratic and true Pancasila [6].

Based on some of the study above, can be drawn a conclusion that the process of civic education in the field is still oriented towards control theory and memorizing it, a school curriculum tends to be rigid and laden with the burden of being unattractive and unable to foster the creativity of people in schools so the success of the learning process to be blocked. During this time, learning Citizenship Education focus only on the understanding and mastery of subject matter of learning Citizenship Education course. In practice, the students only used as an object to measure how much students can master the material given by the teacher. This is of course only will hone students' cognitive abilities and indifferent to the psychomotor and affective aspects of empowerment. Education like this does not prepare students to be able to better interact with their environment when later they blend into society. Through this article the author 
recommends changing the paradigm of civic education educator long conventional civic education toward understanding put forward not only theory but also a learning experience. So being able to empower civic activism to the maximum.

\section{THEORETICAL}

\section{A. Civic Education}

Kerr states that the Citizenship or Civics education is construed broadly to encompass the preparation of young people for Reviews their roles and responsibilities as citizens and, in particular, the role of education (trough schooling, teaching, and learning) in that preparatory process [7]. Based on these opinions can be described that citizenship education has the task to prepare the younger generation to the role and responsibilities as citizens and in particular, the role of education (through school, teaching, and learning) in the process of preparing the younger generation.

The interest of civic education in general is "to form good citizens (to be good citizens)". Good citizens as citizens who understand and are able to implement properly the rights and obligations as individual citizens who have a sensitivity and social responsibility, is able to solve its own problems and also problems of society intelligently according to the function and role, has an attitude of personal discipline, capable of critical thinking creatively and innovative in order to achieve the personal qualities and behavior of citizens and residents who either [8]. While the function of education of citizenship is a conscious effort made scientifically and psychologically to provide ease of learning to the learners to happen internalization of moral Pancasila and knowledge of citizenship to underpin the national education goals, which are embodied in the personal integrity and daily behavior [6].

Based on some statements about the nature of citizenship education mentioned above, it can be the core of how the purpose and function of the civic education who want every citizen is able to properly carrying out the rights and obligations as citizens. Not only that, the civic education also wants citizens who have the sensitivity and social responsibility so that they are able to solve his own problems and the problems that exist in the Community smartly. Not just criticize the policies made by the government but also able to provide solutive advice and applicable so as to assist the government in carrying out its duties and responsibilities.

\section{B. Civic Activism}

To interpret civic activism, there are opinions that can be used as a reference, namely: We characterize 'civics' as: incorporating specific contexts in which relevant issues are raised and around which activists mobilize; enjoying a conceptual underpinning in, for example, power, authority, justice; and emphasizing the public and collective (without neglecting contributions of, or impacts on, individuals, and without failing to recognize personal engagement) [9].
Civic activism refers to the social norms, organizations, and practices which facilitate greater citizen involvement in public policies and decisions. These include access to civic associations, participation in the media, and the means to participate in civic activities such as nonviolent demonstration or petition. Civic activism is essential in ensuring that public institutions function in an accountable and transparent manner, with participation and representation for all [10].

So, civic activism focused to their movements or activities that emphasize to the public and begins with the issues that surround us are driven by activists. Such activities not only in government, but more extensive. In these activities, the community must contribute fully, they must know the concept, they will generate an impact on anyone and nor can ignore personal involvement.

The concept was reiterated that the role of active community (not just the concept) in any state activity. Not only are they able to give criticism against the government, but can move by itself on the basis of rights and obligations as a citizen to be able to contribute fully to the development of Indonesia's national life.

\section{METHOD}

The research method used in this article is a literature review. Study of literature or literature, apart from looking for secondary data sources that will support the research, it is also necessary to find out where science-related research has been growing, up to where there are conclusions and generalizations ever made so that the situation required was obtained [11].

This activity (preparation of literature review) aims to collect scientific data and information, in the form of theories, methods, or approaches that once flourished and has been documented in the form of books, journals, manuscripts, records, historical records, documents, etc. contained in the library [12].

Presentation of descriptive literature review with shaped analysis description is also accompanied by an explanation of the differences and similarities. Thus, a literature review indicate where the author's position in relation to the research that has been done, whether to reject, criticize, accept, and or others [12].

\section{RESUlTS AND DISCUSSION}

After reviewing the literature, the authors can say that civic education is very suitable as an attempt to strengthen civic activism. This is in accordance with the purpose of civic education in general that "to form good citizens (to be good citizens)". Good citizens as citizens who understand and are able to implement properly the rights and obligations as individual citizens who have a sensitivity and social responsibility, is able to solve its own problems and also problems of society intelligently according to the function and role, has an attitude of personal discipline, capable of critical thinking creatively and innovative in order to achieve 
the personal qualities and behavior of citizens and residents who either [8].

From this opinion was reinforced by what is to be a benchmark in the concepts of civic activism, civic activism refers to the social norms, organizations, and practices which facilitate greater citizen involvement in public policies and decisions. These include access to civic associations, participation in the media, and the means to participate in civic activities such as nonviolent demonstration or petition. Civic activism is essential in ensuring that public institutions function in an accountable and transparent manner, with participation and representation for all [10].

Based on some of these opinions, conceptually civic education is able to strengthen civic activism. This is because the corridors of civic activism itself is one study of civic education, where citizens can carry out activities that involve direct between the community and society and society with the government. More important are the activities that people not only understand in theory but was able to participate on the grounds that they understand the concept and what it does impact on them. It also supports the goals of civic education in general is to make citizens "smart and good".

The next problem in the field is how to internalize the values of civic activism into civic education in each educational unit. It is said in the introduction that civic education in Indonesia is still conventional. In which only emphasizes learning on students' cognitive aspects of the students were only required to understand educational materials citizenship only that aspect of the skills that should be the learning objectives can not be achieved. Of course this is not it hinder the process in achieving the goals of civic education as well.

Citizenship or civics education is construed broadly to encompass the preparation of young people for Reviews their roles and responsibilities as citizens and, in particular, the role of education (trough schooling, teaching, and learning) in that preparatory process [7]. At the present time the presence of civic education should really be interpreted as a road that is expected to usher in the nation of Indonesia creating democracy, good governance, rule of law and civil society idealized by the entire community [13]. It is aligned with that presence civic education today should be able to answer all questions about civic activism so as to prepare the younger generation in order to determine the role and responsibilities as citizens through schools, teaching and learning so as to create a civil society that are desired by all people of Indonesia.

\section{CONCLUSION}

After reviewing the results obtained from literacy, it can be concluded that civic education is able to empower civic activism in an effort to achieve the educational goals of citizenship itself. Furthermore, the authors suggested that civic education practitioners to change the old paradigm of conventional civic education towards not only promote understanding of theory, but also a learning experience. So as to empower civic activism to the maximum.

\section{REFERENCES}

[1] Winataputra, U.S. Jati Diri Pendidikan Kewarganegaraan sebagai Wahana Sistemik Pendidikan Demokrasi: Suatu Kajian Konseptual dalam Konteks Pendidikan IPS. Jurnal Pendidikan Program Pascasarjana, Vol. 1 No 1, February 2002, p. 39-75. 2002.

[2] Winataputra US. Paradigma Pendidikan Kewarganegaraan sebagai Wahana Sistemik Pendidikan Demokrasi. Jakarta: Balitbang DEPDIKNAS. 2001.

[3] Cogan, J.J. Developing the Civic Society: The Role of Civic Education. CICED. Bandung. 1999.

[4] Suryadi, A \& Budimansyah, D. Pendidikan nasional menuju masyarakat Indonesia baru. PT. Genesindo. Bandung. 2004.

[5] Branson, S. M. Belajar civic education dari Amerika. Lkis. Yogyakarta. 1999.

[6] Somantri, N. Menggagas pembaharuan IPS. Remaja Rosdakarya. Bandung. 2001.

[7] Kerr, D. Citizenship Education: an International Comparison. National Foundation for Educational Research-NFER. London. 1999.

[8] Wahab, A.A., \& Sapriya. Teori dan landasan pendidikan kewarganegaraan. Alfabeta. Bandung. 2011.

[9] Davies, I., Evans, Mark \& Peterson, Andrew. Civic activism, engagement and education: Issues and trends. JSSE. Vol, 13. No 4. p-3. 2014.

[10] Civicactivism.buildingchangetrust.org. About civic activism. Northern Ireland. 2017.

[11] Nazir, M. Metode Penelitian. Ghalia Indonesia. Jakarta. 2005.

[12] Prastowo, A. Metode Penelitian Kualitatif dalam Perspektif Rancangan Penelitian. Ar-Ruzz Media.Yogyakarta. 2012.

[13] TIM ICCE. Pendidikan kewarganegaraan, hak asasi manusia, masyarakat madani. Prenada Media. Jakarta. 2005. 